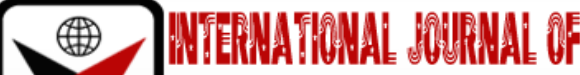

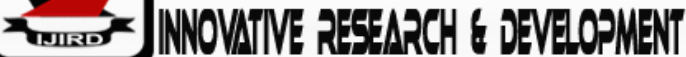

ISSN 2278-0211 (Online)

\section{Influence of Flexible Work Arrangement on Employee Job Performance of National Government Administrative Officers in Kenya}

\author{
Charles Wanyonyi Wesamba \\ Master's Student, Department of Business Administration and Management, \\ Kibabii University, Kenya \\ Dr. Laura Catherine Mamuli \\ Lecturer, Department of Business Administration and Management, \\ Kibabii University, Kenya \\ Dr. Stephen Eshiteti \\ Lecturer, Department of Business Administration and Management, \\ Kibabii University, Kenya
}

\begin{abstract}
:
The Public Service through the NGAO is very vital in delivering to citizens its services. The sector has a huge impact when it comes to the maintenance of order. However, among its many challenges, it is the decline in the employee job performance of many administrators over time. The main objective of the study was to look into WLB practices and employee job performance of NGAO in Bungoma County. The specific objective of the study was to assess how flexible work arrangement influences employee job performance of NGAO in Bungoma County. The study adopted a descriptive research design. The target population included all NGAO in Bungoma County. The sample size was determined by census sampling technique. The study used questionnaires which were self-administered to the respondents to collect specific information. Validity of research tools was ascertained through expert opinion while reliability ascertained by use of Cronbach's alpha. Descriptive and inferential statistics were used to analyse the data with the help of the statistical Package for Social Sciences (SPSS). The findings will be presented in the frequency tables. Results of the study were: there was a statistically positive and significant effect of flexible work arrangement on employee job performance of NGAO in Bungoma County' $\{\beta=0.876$; $R=0.464$, beta $=0.464, F(1,127)=34.878$, $t=5.906, p=0.000\}$. The following were the recommendations of the study: NGAO in Bungoma County should consider and come up with flexible work arrangement policies where they are missing and be entrenched in their strategic plans and implemented to hasten its employee performance and that the working environment should be enhanced in additional to the prevailing WLB practices in the NGAO in Bungoma County, there would be an increase in employee performance.
\end{abstract}

Keywords: Flexible work arrangement, employee job performance, national government administrative officers of Kenya

\section{Introduction}

In our current society, places of work experience a lot of pressures. Demands on target at work, pressure from family and the stress on adjusting the two have negatively affected most workers' wellbeing and prosperity (Parus, 2010). Employers, confronted with soaring health maintenance costs, competition globally, and uncertainty in the economy, are worried about drawing in and holding onto excellent workers and deliver authoritative performance in their organization. Organizations, therefore, create working environments that accomplish something other than improving productivity they don't fabricate a solid, energetic hierarchical culture that underpins the organization itself yet a mentally sound working environment (Greenhaus and Beutell, 2010).

Work life balance (WLB) is an important phenomenon and extraordinary concerned with diverse workers in both public sector and private sector. It goes past arranging the work occupation and one's own special life. In like manner, WLB impacts the mental, social, affordable, and psychological success of an individual. All these are being reflected in the yield of the individual, which impacts their performance in the workplace in eventually. The WLB has implications on workers, mentalities, practices and prosperity (Eby et al., 2005). The competitions for leadership in market in the bank sector, may prompt bank administrators giving their workers unreasonable outstanding amount of work so as to be in line with their objective. Workers attempt their best to be retained in the association by investing more energy at work which 
might be a hindrance to their own life. All these may influence the children upbringing, lead to broken and miserable homes and poor social living.

Flexible work arrangements (FWAs) have as of late increased an extensive prominence generally in EU and OECD countries (Kattenbach et al., 2013). Enormous scope research, for example, the European Working Conditions Surveys (Euro-found, 2017), the place of work Employment Associations Series and the WLB Study (de Menezes et al, 2011) and a current investigation affirm the rising notoriety of FWAs in both exceptionally developed (for example Netherlands, Italy \& UK) and less developed EU nations, namely Romania, Greece and Portugal (Gialis and Taylor, 2016). Different investigations have additionally affirmed expanding proportions of workforce utilizing FWAs in numerous nations globally, for example, Canada, Australia, Japan, and USA (ILO, 2011; OECD, 2012; Spreitzer et al., 2017). The expanding notoriety of FWAs is a consequence of both the associations' longing to acquire flexibility furthermore, institutional suggestions from the EU, OECD and ILO.

Lately, a research investigated the influence of explicit flexibility in working arrangements on firm execution regarding production, turnover, profitability, absenteeism etc. (Dex \& Smith, 2002; Berkery et al., 2017), yet, de Menezes and Kelliher (2011) call attention to a methodical writing review dependent on 148 issuing that past research about the impacts of flexible work arrangement on firms' execution are uncertain and ought to be additionally analyzed. Moreover, writings are totally quiet about various bunches of FWAs enactment, particularly with regard to their essential 'recipients'. All the more decisively, FWAs can be investigated through the perspective of advantages they fundamentally have a place with, whichever those of workers or employers, that is, in relation to the objectives accomplished by various kinds of FWAs (Lewis, 2003; Kotey \& Sharma,2016). Subsequently, the study will investigate the gap in other research present in the writings or literature, to be specific, the absence of point of view that recognizes the way that certain FWAs are make known with costs that are lower (employer driven), though others are planned for lessening work-life strife (driven by the employee), just as to investigate the various impacts of these groups of flexible work arrangements, i.e., their relationship with workers job execution.

The NGAO Officers (NGAO) are recruited and appointed by the Public Service Commission of Kenya in consultation with the Cabinet Secretary and are liable for the National Functions coordination as set out in the constitution of Kenya as well as maintaining of law and order and protection of live and property. The Kenya National Government Administration Department is a department in the Ministry of Interior and Coordination of National Government, under public service. The department is the former Provincial Administration department. It's history dates back to colonial era that Provincial Administration was instituted by colonial powers as a country's institution whose undertakings included a general portrayal of the executive's authority at the grass root level, management of the government's deeds in the ground and presiding committees at the grass root levels (Constitution of Kenya, 2010).

The change of Provincial Administration's name to National Government Administration department was part of restructuring as advocated in the Kenyan Constitution promulgated in the year 2010. It stipulated in Section 17 of the Sixth Schedule on Transitional and Consequential Provisions, that inside five years later the compelling date, the National Government will rebuild the arrangement of organization regularly recognized as the common organization in harmony with and regard the arrangement of reverted government set up under this Constitution (Constitution of Kenya, 2010). The transformed system of administration was enacted through the National Government Coordination Act, No.1 of 2013. The objective of the Act was to institute an institutional and administrative framework for National Government coordination roles at the County and National levels of government's operations, in accordance to the Kenyan Constitution.

In the changed system, the department is headed at the regional level by the Regional Commissioner (RC), previously known as Provincial Commissioner (PC); County headed by County Commissioner (CC); Sub-County previously known as District headed by Deputy County Commissioner (DCC), previously known as District Commissioner (DC); and Ward previously known as Division, headed by the Assistant County Commissioner (ACC) previously known as District Officer (DO). The Assistant Chiefs and Chiefs, who are in charge of sub-locations and locations respectively, retained their titles and areas of jurisdiction.

The administrators' roles have evolved to fit to the devolved system of government and also to address emerging issues. However, the roles have remained decentralized to the grassroots in order to provide its framework which includes coordination and maintenance of public security; management of peace and conflict resolutions; leading campaign against drug and substance abuse; promotion of immigration and registration services; and coordination of National Government functions. These roles require life at work balance practices in all the levels of administration and also in tackling the challenges that face the society. The County Commissioners both the Deputy and Assistant are heads of departments while the Chiefs are heads of sections.

In an inexorably violent condition, the open area has been confronted with complications as its tasks seem to overwhelm and exceed human capacity to accomplish agreeably (Caiden and Sundaram, 2004) which calls for an in-depth study into the same which forms the basis for the present investigation.

\section{Statement of the Problem}

The Public Service through the NGAO is very vital in delivering to citizens its services. The sector has a huge impact when it comes to the maintenance of order. However, among its many challenges, it is the decline in the employee job performance of many administrators over time (Korir, 2013). Among the major cause of this poor performance is lack of balance in work-life practices such as supple work arrangements, programs on wellness, responsibilities for families and conflict in work-life practices (Korir, 2013). The overall performance of the individual employee depends on how such a worker can adjust between their work and individual life with their life as a family (IL0, 2011). As indicated by Korir (2015) the application of balance of work life practices greatly influences performance of work. 
Empirical studies of balancing practices of work life on performance of work by employee has been done in developed nations, for example, United States, China and Britain; others have also been carried out in Kenya (IL0, 2011). However, many of them have related WLB practices other Human Resource outcomes such as organization performance (Kamau, Muleke, Wagoki and Mukaya, 2018), Job satisfaction, Employee engagement, but have inadequately linked the gap between work-life practices and worker job execution in the NGAO Officers, especially in Bungoma County. These are the matters that will prompt the enquiry into WLB practices and employee job performance of the NGAO in Kenya, with special interest to Bungoma County.

\section{Theoretical Framework}

\subsection{Component Theory}

This research study was steered by the Component Theory that was advanced by Edwards and Bagozzi, (2000). This theory underscores balance as an immediate developmental construct which suggests that WLB includes different realities that go before balance and giving meaning. The theory will inform all the goals; one, two three and four in that equivalent balance, fulfillment and work-life help is required for wellbeing program, flexible work course of action, family duty to dodge work life conflict. This theory has been adopted Collins, Greenhaus \& Shaw (2003), who asserted that WLB comprises of the balance of time, balance involvement, and balance fulfillment of which time balance alludes to approach time commitment, participation balance refers to equal mental exertion, and presence contributed and balance gratification alludes to equivalent fulfillment conveyed through roles of family and work. WLB comprises of work-life strife and facilitation of work-life; relating with conflict role and upgrade in that order (Frone, 2003). The benefit of the segment approach over the general reviews way to deal with WLB is that an individual can utilize reasonably founded procedures of equality that tap into the various parts of work-life balance. These perspectives structure the overall assessment of how well a person is achieving role related obligations (Grzywacz \& Carlson, 2007).

Greenhaus, Collins, and Shaw (2003) viewed Work Family Balance as a scale where irregularity for work-life lies toward one side and lopsidedness for the role of family lies at the opposite end and equality lies in the center preferring neither work nor role of the family. In the above conceptualization, work-life equality and inequality are not viewed as characteristically advantageous or unfavorable, respectively, for mental prosperity and quality of life. Rather, Greenhaus et al. (2003) said that it should to be exactly tried whether equivalent time, inclusion and fulfillment balance is preferred for a person over imbalance for either family role or work. In their investigation it worked out that among people with elevated level of commitment crosswise roles, those detailing the utmost caliber of lifecycle where the individuals who put more in the family than the work role that they have indicated an imbalance which favors family. As to their degree of commitment, the similarly balanced people recorded lower in their quality of life than those preferring work over family, however higher than those preferring work over family. Along these lines the people who put most in work had the least life quality.

\subsection{Spillover Theory}

In this theory, there exists a likeness amid what happens in workplace and what happens in the family condition (Sidin, Sambasivan and Ismail, 2010). This theory underlines propensity of laborers to convey their feelings, skills, practices and attitudes that they build up while working and into their family life and the other way around (Sidin et al., 2010). The procedure of spillover can be either negative or positive. The spill that is negative prompts worry in people and the constructive spill can prompt significant heights of performance and fulfillment. Broad investigation into the field of WLB has demonstrated that workers who ceaselessly work extended periods of time have more prominent level of worklife conflict (Dex and Bond, 2005). The limit among work and home is generally weak and will in general overflow positive or negative spills in homes or workplace (Lewis, 2003).

From an authoritative perspective, positive spill over theory can affect the financial prosperity of the association. A fulfilled worker will have spill over impact on their client too, consequently increased execution of an association and the other way around. Increasingly over fulfilled clients are bound to remain devoted to that specific organization and devotion increases higher profitability of an association. The encounters coming about because of spillover in an association can come out as either negative or positive (Morris and Maden, 2007). Spillover that is positive alludes to the degree to which positive encounters in a single space (influence, improvement and capital are moved to another area (influence, advancement and capital) are moved to another area (Powell, 2006) portrayed enhancement of work-family as an indication of spillover that is positive as the level of fulfillment of an individual role, thus enhancing the quality of another role.

The relevance of the hypothesis to this investigation is organizations are expected to adopt constructive work life sense of balance policies that will enable employee have a positive work life sense of equal which will make them effectively committed to achieving the organization's goals. This concept informed objective number one, two, and three. The concept also informed the dependent variable which is performance of the NGAO in that in the event that wellness programs, FWAs, and family perspectives support are concurred to workers, at that point there is probably going to be a positive spill over as far as performance of the NGAO is concerned.

\section{Empirical Literature of Flexible Work Arrangements and Employee Job Performance}

As per an investigation by Hill et al. (2016) explored the connection of work place flexibility, gender and life stage on family-to-work conflict in manufacturing firms in Asia. The study detailed that given a sensible work week which they viewed as somewhere in the range of 40 and 50 hours out of every week, workers who saw adaptability in the planning 
and area of their work, had less trouble with work-family balance. From a business viewpoint, Hill et al. (2016) proposed that given a heavy task at hand, saw adaptability in the planning of work empowers representatives to work an additional day which means 60 hours per week, contrasted with 52 hours without flexible hours.

Therefore work-life adaptability practices give workers the right to alter when, where, and how they work so as to adjust work and non-work requests. Normal structures incorporate leaves for health, caregiving, military, or individual reasons; adaptable schedules, for example, strategic scheduling and telecommuting; and planned work hours. In unionized settings, adaptable planning and leaves might be classified in the aggregate bargaining agreement, yet access to and utilization of work-life adaptability practices regularly fluctuate across employments and offices inside the firm, like nonunion settings. Work-life adaptability incorporates adaptability for family needs as well as more comprehensively, adaptability for laborers who have adaptability needs other than old or children care (Aycan\&Eskin, 2007).

Another study by Lambert (2000) on flexible balance in work life on performance of employee in the South Africa State Corporations; discovered that workers with access to adaptable business plans displayed higher organizational citizenship behaviours, loyalty and productivity. The hypothesis supports that adaptable work routines would diminish work-family conflict, characterized as when one role meddles with another role performance. Utilization of schedules that are adaptable could improve work-family and build it, how much resources or capacities or learning in one section for example work, improve the other, for example, family. This shows clients would have a progressively noticeable commitment in both work and roles in family. The research study further suggests that assets in another domain will spill over and influence assets in another area thus spill over that is positive. They contend that expanded adaptability gave by those schemes of employment will positively affect both work and roles in family. In this manner, workers will have improved prosperity at home and at work, since they will encounter less conflict.

A study by Mwebi and Kadaga (2015) on the impacts of strategic scheduling work course of action on worker execution in Nairobi Central Business District Commercial Banks, proposes that adaptability in work plans can empower workers to incorporate and overlap their work and family duties just as to help them to accomplish a sound harmony between family and work. Adaptable work courses of action benefits both the association and workers where they are associated with various positive results for workers who get to them including better psychological wellness, and decreased stress, burnout, turnover and non-appearance and increments in maintenance, faithfulness, work fulfillment, creativity, innovativeness, productivity and performance. The research study further declared that for an organization that is non-profit making, the adaptability may accompany the capacity to compose setting up in accordance with fluctuating needs of customers or with peaks and troughs of remaining burden. As much as adaptability has favorable circumstances, for example, staff confidence, inspiration, profitability, decreased staff turnover, diminished non-attendance and lessen staffing costs, there are likewise costs related with adaptable plans, for example, set up costs for innovation to telecommute from home. The fruitful enactment of flexi-work course of action adds to a favorable and supportive workplace which empowers the organizations to pull in, spur, and hold esteemed workers who are devoted and focused on taking a significant role in helping their organization make business progress (Mwebi and Kadaga, 2015).

The studies discussed about so far present different shortcomings. To begin with, the example utilized for each situation is small and the analysis depends on cross-sectional information. Furthermore, they investigated the influence of flexible work life balances on performance of employee, but they did not attempt to give a causal interpretation on how employee flex time and flexible career path influence employee job performance. Likewise, the investigations are constrained in one area of economic activity where the elements or controls are not sufficient. For example, the level of rivalry that organizations face from abroad or the local market, the market region, the kind of the organization and the nature of relations among workers and supervisors among different qualities are not thought of.

This study expands the past writing by investigating two dissimilar adaptable work schedules, and it will rely on a data of panel work environments, representing different variables. Furthermore, the study will focus on NGAO as a sample of workers with longer-term contracts. Therefore, this contextual analysis contrasts, as it thinks about permanent workers, who don't have a contract that is temporary or casual. In general, less consideration is paid in the past writing, about flex time role and flexible profession path and their suggestions to the workers performance of work. Besides, the accessibility and adaptation of work that is flexible may vary as per singular attributes of the representatives, associations and segments. For example, age, level of training, marital status can be significant variables of inclination to complete those business types, yet additionally can be critical determinants of performance. The status of the organization, for example, private or public, the competitor, the region which is operated, for example, regional, local or worldwide, the size, the administration employee relations, and the area can be similarly significant elements of performance. This study will offer further bits of knowledge about the administration in the working environment and their control that may consider improvement in productivity.

\section{Methods}

This research study utilized a descriptive research design. Research was carried out in the Bungoma County which is one of the four areas in Western Kenya namely, Vihiga, Kakamega and Busia. Bungoma County is an area in the previous Western Province of Kenya. The study targeted all the NGAO in Bungoma County. The unit of analysis was the individual informant defined as heads of departments (Deputy County and Assistant County Commissioners) and heads of sections (Chiefs). Therefore, the target population consisted of 48 heads of departments and 86 heads of sections (Bungoma County NGAO Report, 2020). Heads of Sections were selected because they oversee the implementation of work life practices while the Heads of Departments were selected since they were the ones that manage the administrative officers' performance in Bungoma County. The sample size consisted of all the 134 heads of departments and heads of sections who were selected using census technique as postulated by Mugenda and Mugenda (2008). Therefore, 48 heads of departments 
and 86 heads of sections were used in the study. Primary data (quantitative data) was collected with the use of the structured questionnaires. Pilot study was conducted in the neighbouring Kakamega County whose findings were not included in the final analysis. Reliability analysis was conducted to test for reliability of the questionnaire items. Cronbach's alpha coefficients of all the constructs were found to be above 0.7 (alpha coefficient $=0.8398$ ), therefore, the test items were retained and used in this study hence considered reliable. The study used construct validity and content validity. Data analysis used both descriptive and inferential statistics where inferential statistics tested the following research hypothesis at $\mathrm{p}$-value of $5 \%(0.05)$ at confidence interval of 95\%: $\mathrm{H}_{0} 1$ flexible work arrangement has no significant influence on employee job performance of NGAO in Bungoma County.

\section{Findings and Discussions}

The objective of the study was to determine the influence of flexible work arrangement on employee job performance of NGAO in Bungoma County. The results are as captured on Table 1.

\begin{tabular}{|c|c|c|c|}
\hline \multicolumn{4}{|l|}{ Descriptive Statistics } \\
\hline Questions Responded to & $\mathbf{N}$ & Mean & Std. Deviation \\
\hline We report to work at varying times & 129 & 3.1473 & 1.14633 \\
\hline $\begin{array}{l}\text { All employees are aware of the rights to request for flexible } \\
\text { working }\end{array}$ & 129 & 1.8217 & 0.89660 \\
\hline I work on full time & 128 & 1.6719 & 0.60326 \\
\hline I have flexibility to work from home & 128 & 2.0234 & 0.71502 \\
\hline $\begin{array}{l}\text { I have regularly scheduled days to be in the office and to } \\
\text { work from home. }\end{array}$ & 128 & 1.6172 & 0.66547 \\
\hline $\begin{array}{l}\text { My schedule fluctuates based on work demands, but I } \\
\text { generally work from home at least one day a week. }\end{array}$ & 128 & 1.8281 & 0.75409 \\
\hline $\begin{array}{c}\text { Most of my time is spent in the office, but I occasionally } \\
\text { work from home }\end{array}$ & 128 & 3.8516 & 0.58981 \\
\hline $\begin{array}{l}\text { I utilize Skype or other video tools to communicate with } \\
\text { colleagues while working from home }\end{array}$ & 128 & 3.964 & 0.5953 \\
\hline I track and report daily activities while working at home & 128 & 2.3125 & 0.87619 \\
\hline $\begin{array}{l}\text { There is provision of training to employees and } \\
\text { management on how to be a successful with flexible work } \\
\text { schedules }\end{array}$ & 128 & 1.7344 & 0.87380 \\
\hline Organization has a formal written flexibility policy & 129 & 1.814 & 1.1164 \\
\hline $\begin{array}{l}\text { Workplace flexibility is believed to have an overwhelmingly } \\
\text { positive effect on engagement, motivation and satisfaction. }\end{array}$ & 129 & 3.8915 & 1.61652 \\
\hline Organization offers work flexibility option to all employees & 129 & 1.8217 & 0.89660 \\
\hline Valid N (list wise) & 128 & & \\
\hline
\end{tabular}

Table 1: Descriptive Statistics of Flexible Work Arrangement and

Employee Job Performance of NGAO Source: Survey Data, (2019)

Findings from Table 1 illustrated that that employees reported to work at varying times at a mean response of 3.1473 and an S.D $=1.14633$. Subsequent observations indicate that, the employees were aware of the rights to request for flexible working at a mean response of 1.8217 and an S.D $=0.89660$; the question on employees working had a mean response of 1.6719 and an S.D =.60326; human resource having the flexibility to work from home had a mean response of 2.0234 with S.D $=0.71502$. the question on employees having regularly scheduled days to be in the office and to work from home a mean response of 1.6172 and an S.D $=0.66547$. Question on the schedule fluctuating based on work demands, but generally work from home at least one day a week had a mean response of 1.8281 and an S.D $=0.75409$. Respondents indicated that most of their time is spent in the office, but occasionally work from home had a mean response of 3.8516 and an S.D $=0.58981$. Similarly, employees utilized Skype or other video tools to communicate with colleagues while working from home with a mean response of 3.964 and an S.D $=0.5953$. Further study outcomes indicated that, respondents track and report daily activities while working at home at a mean response of 2.3125 and an S.D $=0.87619$. It was reported that there was provision of training to employees and management on how to be a successful with flexible work schedules at a mean response of 1.7344 and an S.D $=0.87380$. Respondents were of the views that organization has a formal written flexibility policy at a mean response of 1.814 and an S.D $=1.1164$. Workplace flexibility was believed to have an overwhelmingly positive effect on engagement, motivation and satisfaction had a mean response of 3.8915 and an S.D $=1.61652$. Lastly, respondents illustrated that organization offers work flexibility option to all employees with a mean response of 1.8217 and an S.D $=0.89660$. These descriptive statistics outcomes on flexible work arrangement and employee job performance of NGAO illustrated that the respondents had varied views (views were not similar) on the subject matter.

The objective was to determine the influence of flexible work arrangement on employee job performance of NGAO in Bungoma County. The results are as illustrated in Table 2. 


\begin{tabular}{|c|c|c|c|c|c|c|c|c|}
\hline \multicolumn{9}{|c|}{ Model Summary } \\
\hline \multirow[t]{2}{*}{$\mathrm{R}$} & \multirow{2}{*}{$\begin{array}{c}\mathrm{R} \\
\text { Square }\end{array}$} & \multirow{2}{*}{$\begin{array}{l}\text { Adjusted } \\
\text { R Square }\end{array}$} & \multirow{2}{*}{$\begin{array}{l}\text { Std. Error } \\
\text { of the } \\
\text { Estimate }\end{array}$} & \multicolumn{5}{|c|}{ Change Statistics } \\
\hline & & & & $\begin{array}{l}\text { R Square } \\
\text { Change }\end{array}$ & $\begin{array}{c}\mathrm{F} \\
\text { Change }\end{array}$ & df1 & df2 & $\begin{array}{c}\text { Sig. F } \\
\text { Change }\end{array}$ \\
\hline $0.464^{\mathrm{a}}$ & 0.215 & 0.209 & 0.52498 & 0.215 & 34.878 & 1 & 127 & 0.000 \\
\hline
\end{tabular}

Table 2: Flexible Work Arrangement on Employee Job Performance

a. Dependent Variable: Employee Job Performance

b. Predictors: (Constant): Flexible Work Arrangement

Results in Table 2 show the amount of variation on employees' job performance as explained by FWA which was the predictor variable. There was a positive and significant relationship between FWA and employees' job performance $(\mathrm{r}=0.464, \mathrm{p} \leq 0.05)$. The $\mathrm{R}$-square value of $0.215\left(\mathrm{R}^{2}=0.215\right)$, implies that $21.5 \%$ of the corresponding change in the dependent variable (EJP) could be predicted by flexible work arrangement. The rest could possibly be explained by other variables not in this model. Results gave the $F$ test value of $34.878, p<0.000$ which was large enough to support the goodness of fit of the model. Results do confirm the significant role played by the flexible work arrangement as a predictor variable on employees' job performance.

\begin{tabular}{|c|c|c|c|c|c|}
\hline \multicolumn{6}{|c|}{ Coefficients $^{a}$} \\
\hline \multirow[t]{2}{*}{ Model } & \multicolumn{2}{|c|}{$\begin{array}{c}\text { Unstandardized } \\
\text { Coefficients }\end{array}$} & $\begin{array}{c}\text { Standardized } \\
\text { Coefficients }\end{array}$ & \multirow[t]{2}{*}{$\mathbf{t}$} & \multirow[t]{2}{*}{ Sig. } \\
\hline & $\boldsymbol{\beta}$ & Std. Error & Beta & & \\
\hline (Constant) & 0.108 & 0.369 & & 0.293 & 0.770 \\
\hline OBJ1 & 0.876 & 0.148 & 0.464 & 5.906 & 0.000 \\
\hline
\end{tabular}

Table 3: Flexible Work Arrangement on Employee Job Performance Coefficients Significance Level, $p \leq 0.05$

a. Dependent Variable: EJP

b. Predictors: (Constant): Flexible Work Arrangement

Table 3 gives a regression coefficient $(\beta)$ of 0.876 which implies that FWA has a strong positive association to EJP of NGAO in Bungoma County. From the model, when FWA is adjusted by one unit, there would be a corresponding change in EJP of NGAO in Bungoma County by 0.464 units. Considering Hypothesis One $\left(\mathrm{H}_{0} 1\right)$ that, FWA has no significant influence on EJP of NGAO in Bungoma County the results indicate that, there was a statistically positive and significant effect of FWA on EJP of NGAO in Bungoma County' $\{\beta=0.876 ; R=0.464$, beta=0.464, $F(1,127)=34.878, t=5.906, p=0.000\}$. The null hypothesis that, 'FWA has no significant influence on EJP of NGAO in Bungoma County,' was rejected and the alternate accepted.

These finding are comparable to study by Lambert (2000) on flexible balance in work life on performance of employee in the South Africa State Corporations; discovered that workers with access to adaptable business plans displayed higher organizational citizenship behaviours, loyalty and productivity. The hypothesis supports that adaptable work routines would diminish work-households conflict, characterized as when one role meddles with another role performance. Utilization of schedules that are adaptable could improve work-households and build it, how much resources or capacities or learning in one section for example work, improve the other, for example, households. This shows clients would have a progressively noticeable commitment in both work and roles in households. The research study further suggests that assets in another domain will spill over and influence assets in another area thus spill over that is positive. They contend that expanded adaptability gave by those schemes of employment will positively affect both work and roles in households. In this manner, workers will have improved prosperity at home and at work, since they will encounter less conflict.

\section{Conclusions and Recommendations}

With R-square change of 0.215 obtained, $21.5 \%$ of the observed change in employee job performance of NGAO in Bungoma County was attributed to flexible work arrangement. Considering Hypothesis One (H01) that, 'flexible work arrangement has no significant influence on employee job performance of NGAO in Bungoma County' the results indicate that, there was a statistically positive and significant effect of flexible work arrangement on employee job performance of NGAO in Bungoma County' $\{\beta=0.876$; $R=0.464$, beta=0.464, $F(1,127)=34.878, t=5.906, p=0.000\}$. The null hypothesis that, 'flexible work arrangement has no significant influence on employee job performance of NGAO in Bungoma County,' was rejected and the alternate accepted.

Recommendations of this piece of work are: First, following the conclusion that $21.5 \%$ of the observed change in employee job performance of NGAO in Bungoma County was attributed to flexible work arrangement, therefore, this study recommends that NGAO in Bungoma County should consider and come up with flexible work arrangement policies where they are missing and be entrenched in their strategic plans and implemented to hasten its employee performance. 


\section{Abbreviations}

- NGAO : National Government Administrative Officers,

- WLB : Work Life Balance,

- FWA : Flexible Work Arrangement,

- FWAs : Flexible work arrangements,

- EJP : Employee Job Performance,

- SD : Standard Deviation,

- ILO : International Labour Organization,

- OECD : Organisation for Economic Co-operation and Development

\section{References}

i. Berkery, E., Morley, M. J., Tiernan, S., Purtill, H., \& Parry, E. (2017). On the uptake of flexible working arrangements and the association with human resource and organizational performance outcomes. European Management Review, 14(2), 165-183. https://doi.org/10.1111/ emre.12103

ii. Caiden, G., \& Sundaram, P. (2004). The Specificity of Public Service Reform. Public Administration \& Development, 24(5), 373-383.

iii. deMenezes, L. M., \& Kelliher, C. (2011). Flexible working and performance: A systematic review of the evidence for a business case. International Journal of Management Reviews, 13(4), 452-474. https://doi. org/10.1111/j.1468-2370.2011.00301.x

iv. Dex, S., \& Smith, C. (2002).The nature and pattern of family-friendly employment policies in Britain. Bristol, UK: The Policy Press.

v. Eby, L. T., Casper, W. J., Lockwood, A., Bordeaux, C., \&Brinley, A. (2005). Work and family research in IO/OB: Content analysis and review of the literature (1980-2002). Journal of Vocational Behavior, 66(1), 124-197.

vi. Frone, M. R. (2003). Work-family balance. In J. C. Quick \& L. E. Tetrick (Eds.), Handbook of occupational health psychology (pp.143-162). Washington, DC: American Psychological Association.

vii. Gialis, S., \& Taylor, M. (2016). A regional account of flexibilization across the EU: The 'flexible contractual arrangements' composite index and the impact of recession. Social Indicators Research, 128(3), 1121-1146. https://doi.org/10.1007/105 s11205-015-1072-9

viii. Greenhaus, J.H., and Beutell, N.J. (2010), Sources of conflict between work and family roles. Academy of Management Review, 10, 76-88.

ix. Greenhaus, J. H., Collins, K. M., \& Shaw, J. D. (2003). The relation between work-family balance and quality of life.Journal of Voca-tionalBehavior, 63,510-531

x. Grzywacz, J. G., \& Carlson, D. S. (2007). Conceptualizing work-family balance: Implications for practice and research.Advances in Devel-oping Human Resources, 9,455-471

xi. Hill, J., Jacob, I., Shannonb, L., Brennanc, T., lancharda, V. l., \& Martinengoa, G. (2016). Exploring the relationship of workplace flexibility, gender and life stage to family-to-work conflict \& stress \& burnout. Community, Work and Family, 11(2), 165-181.

xii. International Labour Organization (2011).Working time in the twenty--first century: Discussion report for the Tripartite Meeting of Experts on Working-Time Arrangements 2011. Geneva: International Labour Office.

xiii. Kamau, J. M, Muleke V, Makaya S. O, and Wagoki, J. (2013) Work life balance practices on employee performance of Ecobank Kenya. European journal business and management, 5(25), 179-185.

xiv. Kattenbach, R., Demerouti, E., \& Nachreiner, F. (2013). Flexible working times: Effects on employees' exhaustion, work-nonwork conflict and job performance. Career Development International, 15(3), $279-295$. https://doi.org/10.1108/13620431011053749.

xv. Korir, W. (2013).An analysis on performance of container freight station at the port of Mombasa in Kenya. International Journal of Advanced Research, 1(10), 731-738.

xvi. Kottey, B., \& Sharma, B. (2016).Predictors of flexible working arrangement provision in small and medium enterprises (SMEs).The International Journal of Human Resource Management, 27(22), 2753-2770. https://doi.org/10.1080/09585192.2015.1102160.

xvii. Lambert, S. J. (2000). Added benefits: The link between work-life benefits and organizational citizenship behavior. Academy of Management Journal, 43 (5), 801-815.

xviii. Lewis, S. (2003). Flexible Working arrangements: Implementation, outcomes, and management. In C. Cooper, \& I. Robertson (Eds.), International Review of Industrial and Organizational Psychology, 18, 1-28.

xix. Morris, M. L., \& Madsen, S.R. (2007).Advancing work life integration in individuals, organizations and communities. Advances in Developing Human Resources, (9), 439-454.

xx. Mugenda, O., \& Mugenda, A. (2008).Research methods quantitative and qualitative approaches. Nairobi: Acts Press.

xxi. Mwebi, M., \& Kadaga, M. (2015).Effects of flextime work arrangement on employee performance in Nairobi CBD Commercial Banks: International. Journal of Novel Research in Marketing Management and Economics, 2 (3), 111-121.

xxii. National Government Coordination Act, No.1 of 2013

xxiii. OECD (2012).Employment Outlook 2012.Paris: OECD Publishing. https://doi.org/10.1787/empl_outlook2012-en

xxiv. Powell, D.R. (2006). Characteristics of successful wellness programs 'Employee benefits Journal, 24(3). 
xxv. Spreitzer, G. M., Cameron, L., \& Garrett, L. (2017). Alternative work arrangements: Two images of the new world of work. The Annual Review of Organizational Psychology and Organizational Behavior, 4(1),

xxvi. $\quad$ 473-499.https://doi.org/10.1146/annurev-orgpsych-032516-113332.

xxvii. The Constitution of Kenya (2010). 